\title{
JUSTICE IN COMMERCIAL MATTERS: HISTORY OF DEVELOPMENT AND NOVELTIES OF UKRAINIAN REFORM
}

\author{
Prytyka Dmytro, \\ Doctor of Judicial Science, professor, \\ Ex-Head of the Supreme Commercial Court of Ukraine
}

Summary: 1. Introduction. - 2. The History of Ukrainian Commercial Courts Development. - 3. Novels of Commercial Procedure in the Context of Judicial Reform. - 4. Concluding Remarks.

\section{INTRODUCTION}

The judicial system of commercial (arbitration) courts of Ukraine has undergone a difficult path of formation and approval. An active process of creating the system of arbitration courts in Ukraine began in 1991, with the adoption by the Verkhovna Rada of Ukraine of the Law of Ukraine 'On the Arbitration Court. This law defined the prerogatives of the arbitration court as one of the branches of the judiciary designed to administer justice in commercial relations. The main peculiarity of the arbitration court as a part of the judiciary was its specialization. Today we are the witnesses of the final stage of the reform of commercial courts and commercial justice as a whole within the adoption of the Law of Ukraine 'On the Judiciary and Status of Judges' in 2016.

Within current judicial reform in Ukraine, not only the organization of the courts itself, but also the procedure for reviewing commercial cases has changed. The main novels of commercial justice, analysed in this paper, are the following: reflection of the main purpose of the CPC and the basic principles, among which there are new ones: proportionality and case management; more complete implementation of the principles of publicity and openness, etc.; introduction of electronic justice; differentiation of proceedings; determining the written statements of the participants of the case and the written form of the proceedings; improvement of the procedure of proof in the case, as well as distribution of court costs in the case, taking into account the main elements of case management and the need to ensure the principle of cooperation between the court and the parties in the case; as well as the prevention of confusion with procedural rights in the process and the settlement of a dispute with the participation of a judge. 


\section{THE HISTORY OF UKRAINIAN COMMERCIAL COURTS DEVELOPMENT}

\subsection{The OriginsofCommercialCourts'EstablishmentinUkraineandConstitutional Basis for Justice Administration by Courts}

The adoption of the Law of Ukraine 'On the Arbitration Court' and the Arbitration Procedural Code of Ukraine (APC of Ukraine) was only the first step in the legislative provision for the organization and activities of such specialized courts as arbitration courts.

Important directions for improving the organization and functioning of arbitration courts were contained in the 'The concept of judicial reform in Ukraine', adopted by the Verkhovna Rada of Ukraine on 28 April, 1992, which, according to V. Stashys, 'played a generally positive role both in determining the main directions of the courts' reform, and in establishing a range of associated problems without which it is impossible to establish a judiciary as an independent branch of state power. The practical implementation of certain components of the judicial and legal reform was the adoption on 15 December, 1992 of the Law of Ukraine 'On the Status of Judges', which, for the first time in the history of Ukrainian legislation, stipulated that judges are the sovereigns of the judiciary and administer justice regardless of legislative and executive power (Item 1 of Article 1). This Law established important guarantees of the independence of judges, provided for their political and business neutrality. With the adoption of new laws relating to the judiciary, the issue of the affiliation to this power of the arbitral courts was unambiguously resolved. Thus, on 2 February, 1994, the Verkhovna Rada of Ukraine adopted two laws that were of fundamental importance from the point of view of assigning arbitration courts to the judiciary. These are the Laws of Ukraine 'On bodies of judicial self-government' and 'On qualification commissions, qualification attestation and disciplinary responsibility of judges of Ukraine'.

Thus, within a few years after the proclamation of the independence of Ukraine in 1991, a certain legal basis was created to support the activity of arbitration courts.

The new Constitution of Ukraine, adopted by the Verkhovna Rada of Ukraine on 28 June, 1996, established a fundamental legal framework aimed at ensuring the further development of judicial reform in Ukraine. Section VIII 'Justice' of the Constitution has established that: justice in Ukraine shall be administered exclusively by the courts; delegation of functions of courts or appropriation of such functions by other bodies or officials shall be prohibited; the jurisdiction of the courts shall extend to all legal relations that arise in the state; judicial proceedings shall be performed by the Constitutional Court of Ukraine and courts of general jurisdiction; people shall directly participate in the administration of justice through people's assessors and jurors; court decisions shall be adopted by the courts in the name of Ukraine and shall be mandatory for execution throughout the entire territory of Ukraine (Article 124). Article 125 of the Constitution of Ukraine stipulates that: the system of courts of general jurisdiction in Ukraine shall be formed in accordance with the territorial principle and the principle of specialization; the highest judicial body in the system of courts of general jurisdiction is the Supreme Court of Ukraine; the respective high courts shall be the highest judicial bodies of special- 
ized courts; courts of appeal and local courts shall operate in accordance with the law; establishment of extraordinary and special courts shall not be permitted. The Constitution of Ukraine really 'defined specific benchmarks for the construction of a new judicial system that could effectively fulfil its primary function of protecting the rights and freedoms of a person and a citizen'.

Certainly, it took time to bring the judicial system in line with the Constitution of Ukraine. Therefore, in accordance with Clause 12 of the 'Transitional Provisions' of the Constitution of Ukraine, the system of general, military and arbitration courts valid at the time of adoption of the Fundamental Law should have been reformed within five years into a single system of courts of general jurisdiction provided for by Article 125 of the Constitution. That is, the transition period ought to have such chronological limits: June 1996 - June 2001.

After the adoption of the Constitution of Ukraine, a number of measures were taken to improve the organization and functioning of arbitration courts. Thus, on 20 February, 1997, the Verkhovna Rada of Ukraine adopted the Law of Ukraine 'On Amendments to the Law of Ukraine "On the Arbitration Court". By this law, in particular, consideration of cases of bankruptcy was assigned to the jurisdiction of arbitration courts. Amendments were made to Article 4 of the Law of Ukraine 'On the Arbitration Court', which contained the principles of the organization and activities of the arbitration court. This article was supplemented by a very important for the activity of such a court provision indicating that the arbitration court shall administer justice based on a principle of 'adversary procedure between parties and the freedom of parties to provide the arbitration court with their evidence and to prove their credibility'. Articles 20-29 of Section III 'The Status of Arbitrators of the Arbitration Court' were replaced with Articles 20-22, the content of which was radically different from the content of Articles 20-29. In addition, according to paragraph 10 of the Law of Ukraine of 20 February, 1997, the words 'arbitrator', 'arbitration panel', 'Republic of Crimea' in all cases were replaced with the words 'judge,' 'judicial panel', 'Autonomous Republic of Crimea' in corresponding cases in the text of the Law of Ukraine 'On the Arbitration Court.' The replacement of the words 'arbitrator', 'arbitration panel' with the words 'judge,' 'judicial panel' further emphasized the legal nature of the arbitration courts as specialized judicial bodies for the administration of justice in commercial affairs.

In 1993-2001 a number of amendments and additions were made to the Arbitration Procedural Code of Ukraine. On the basis of the Constitution of Ukraine, the legislation of Ukraine on the arbitration court, arbitration proceedings, other legislative acts of Ukraine, international treaties, the consent to be bound by which was provided by the Verkhovna Rada of Ukraine, the organization and operation of bodies of commercial jurisdiction was carried out during the decade (from 1991 to the middle of 2001).

The power of arbitration courts to define the range of issues which are under their jurisdiction is secured by Article 12 of the Arbitration Procedural Code (hereinafter - APC). This article stipulates that arbitration courts shall settle disputes, which arise during the conclusion, modification, termination and execution of commercial agreements, etc, as well as disputes concerning the invalidation of acts on the 
grounds, specified in the legislation; issues concerning bankruptcy; cases upon requests of the bodies of Antimonopoly Committee of Ukraine on matters which are placed under their jurisdiction by acts. It should be noted that, based on the nature of arbitration court as a body for the administration of justice in commercial issues, the legislator quite rightly expanded the range of commercial disputes for consideration by arbitration courts. For example, previously state arbitration courts had no right to consider disputes concerning taxes and non-taxable payments charged to the state budget, disputes for the value of less than 100 karbovanets, disputes between enterprises, organizations and institutions that arose in connection with the implementation of bank financial control over non-use of funds for capital contributions. These categories of disputes were considered by the executive authorities. Before the adoption of the Arbitration Procedural Code some categories of commercial disputes were considered by the general courts. Such disputes included disputes involving foreign legal entities, joint ventures, international associations and organizations of the USSR and other countries not members of the CMEA; disputes arising from contracts for the carriage of goods in direct international rail and air freight traffic between public enterprises, institutions, organizations, on the one hand, and railway or air transport authorities, on the other hand; disputes involving collective farms, inter-farm enterprises, organizations or their associations.

It is quite natural that these disputes, having objectively commercial characteristics, were attributed by the APC of Ukraine to the jurisdiction of arbitration courts. Consequently, in the person of arbitration courts, the judiciary received specialized judicial bodies, which had prerogatives to resolve commercial disputes previously considered by general courts, as well as by executive authorities.

At the same time, it should be noted that Article 12 of the Law of Ukraine 'On Arbitration Court' had earlier provided the Supreme Arbitration Court of Ukraine with the right of legislative initiative to the Verkhovna Rada of Ukraine. However, the Constitution of Ukraine of 1996 did not grant the Supreme Arbitration Court of Ukraine such a right.

In accordance with Article 5 of the Law of Ukraine 'On the Arbitration Court', the Supreme Arbitration Court of Ukraine, the Arbitration Court of the Autonomous Republic of Crimea, the arbitration courts of regions, the cities of Kyiv and Sevastopol acted in Ukraine, forming a single harmonious system of arbitration courts of Ukraine. The entire system of arbitration courts of Ukraine was headed by the Supreme Arbitration Court of Ukraine, which was the supreme body in resolving commercial disputes and overseeing decisions, rulings, decisions of arbitration courts in Ukraine and controlling their activities. According to the Law of Ukraine 'On the Arbitration Court', the Supreme Arbitration Court of Ukraine issued guidance clarifications on the basis of the generalization and analysis of the judicial practice of the application of the rules of substantive and procedural law that were binding for arbitration courts and enterprises, organizations, state and other bodies and officials. Such explanations were approved by the resolutions of the Plenum of the Supreme Arbitration Court of Ukraine and were brought to the attention of interested persons through the mass media, as well as by other means established by the legislation. The Supreme Arbitration Court of Ukraine consisted of the Head of the Supreme 
Arbitration Court, the First Deputy Head, Deputies Head and Judges, and acted as part of the Plenum of the Supreme Arbitration Court of Ukraine, the Presidium of the Supreme Arbitration Court of Ukraine, the Judicial Panel on Dispute Resolution and the Judicial Board on Reviewing Decisions, decrees, rulings. Based on the Resolution of the Verkhovna Rada of Ukraine 'On the Enforcement of Courts' of 24 February, 1992, the Supreme Arbitration Court of Ukraine established the Research Centre, which was to deal with the complex problems of the organization and competence of the jurisdictional authorities in resolving commercial disputes and improving the qualifications of judges and specialists of arbitration courts of Ukraine.

In order to provide a qualified review of the most relevant categories, necessary structural changes were made in arbitration courts. According to the Decree of the President of Ukraine dated 21 April, 1998, special boards of bankruptcy proceedings were formed in the composition of the arbitration courts, and on 13 August, 1999, the board for consideration of cases of collection of taxes and fees (compulsory payments) was established. This contributed to the increase of the effectiveness of judicial protection of economic legal entities, including the state as a guarantor for the implementation of social programs.

The full implementation of the principles of arbitration provided by the Law of Ukraine 'On the Arbitration Court' was approved by the APC of Ukraine, adopted on 6 November, 1991, which defined the jurisdiction of the arbitration courts, clearly defined the procedural rights and obligations of the participants in the arbitration process, regulated the procedure of reviewing the disputes, making decisions concerning them, checking the legality of the latter. The practice of resolving commercial disputes in accordance with the norms of the Arbitration Procedural Code of Ukraine (in force since 1 March, 1992 (with subsequent amendments and supplements) as a whole confirmed their objective viability, since the number of amended and cancelled procedural documents during 1992-2000 did not exceed 1.7 per cent from the total number of cases considered.

Since the adoption by the Verkhovna Rada of Ukraine of the Law 'On the Arbitration Court' and until the middle of 2001, the Ukrainian Arbitration Courts had passed the period of establishment and development and confidently occupied their place in the system of justice, carrying out the function entrusted to them for the protection of rights and interests of the participants of commercial legal relations, contributing to the development of cooperation between them, making proposals aimed at improving the legal regulation of commercial activity. Arbitration courts have accumulated experience of 'collaboration that takes into account the specific and independent character of the procedural status of judges and prosecutors, to strengthen the rule of law in the commercial sphere, protect the interests of the state and society, the legitimate rights and interests of business entities.' For the system of arbitration courts, common features such as simplicity of construction in accordance with the administrative-territorial division, availability for plaintiffs, hierarchy of structure, the unity of the system of arbitration courts, conditioned by the unity of their tasks, the sole principles of the organization and operation of these courts have become common. The multifaceted activity of the arbitration courts of Ukraine during the decade of their operation proved convincingly that they have 
really become 'specialized courts for the administration of justice in commercial relations, as part of a unified system of bodies of the judiciary. During this period of time, the bodies of arbitral proceedings as a specialized system of judicial authorities have considered about one million cases, the vast majority of which were associated with property relations. Arbitration courts of Ukraine actively influenced the formation of new economic relations in the state.

One of the most important directions of the activity of arbitration courts was to improve the legal regulation of economic legal relations. Proposals for the improvement of the legislation introduced by the Supreme Arbitration Court of Ukraine for the entire period of existence of the system of arbitration proceedings covered the most important aspects of economic activity: privatization processes, lease, foreign economic and cooperative activities, crediting, bankruptcy of business entities, conclusion of intergovernmental economic agreements and others.

\subsection{As Arbitration Courts Became the Commercial Courts of Ukraine}

In June 2001 expired the five-year term of the item 12 of the 'Transitional Provisions' of the Constitution of Ukraine of 1996 on the functioning of the old judicial system. The rejection of legislative acts on the development of the provisions of Article 125 of the Constitution created, as V.V. Komarov rightly observes, the threat of the removal of the judicial system and legal proceedings 'from the constitutional field.' Therefore, on 21 June, 2001, the Verkhovna Rada of Ukraine promptly adopted the following laws: "On Amendments to the Law of Ukraine 'On the Judiciary of Ukraine', 'On Amendments to the Criminal Procedure Code of Ukraine,' 'On Amendments to the Law of Ukraine "On the Status of Judges"', 'On Amendments to the Law of Ukraine "On Judicial Self-Government Bodies", 'On Amendments to the Law of Ukraine "On Qualification Commissions, Qualification Certification and Disciplinary Liability of Judges of the Courts of Ukraine"', 'On Amendments to the Law of Ukraine "On the Arbitration Court"', 'On Amendments to the Arbitration Procedural Code of Ukraine', 'On Amendments to the Civil Procedure Code of Ukraine.' The purpose of adopting these laws was, first of all, ensuring compliance with the requirements of paragraph 12 of the 'Transitional Provisions' of the Constitution of Ukraine. In deputy journalist circles, as well as scholar circles, amendments, introduced by the said laws to the judicial system and judicial proceedings, received the name 'small judicial reform.' This reform brought a number of significant changes both to the court procedure and to the Ukrainian judicial system. These changes also touched upon the arbitration courts of Ukraine.

At present, according to Article 20 of the Law of Ukraine 'On the Judiciary of Ukraine', in the wording of 21 June 2001, the system of courts of general jurisdiction, in accordance with the Constitution of Ukraine, consisted of 'local courts, appellate courts, higher specialized courts, and the Supreme Court of Ukraine.' According to paragraph 1 of the Law of Ukraine of 21 June, 2001 'On Amendments to the Law of Ukraine "On the Arbitration Court", the title of this Law was set forth in the following wording: 'The Law of Ukraine on Commercial Courts.' According to paragraph 26 of the Law of Ukraine 'On Amendments to the Law of Ukraine "On the Arbitration Court"' of 21 June, 2001, in the text of the Law of Ukraine 'On the 
Arbitration Court' the word 'arbitration' in all cases was replaced with the word 'commercial' in the corresponding cases. Thus, commercial courts began to enforce justice in commercial relations. The system of these courts was enshrined in Article 5 of the Law of Ukraine 'On Commercial Courts', which stated that 'commercial courts are specialized courts in the system of courts of general jurisdiction. Commercial courts constitute a unified three link system of specialized courts, consisting of: local commercial courts; appellate commercial courts; Supreme Commercial Court of Ukraine.' The following articles of the Law of Ukraine 'On Commercial Courts' specified and detailed the organization and procedure of the activities of all sections of commercial courts of Ukraine. The Final and Transitional Provisions of the Law of Ukraine 'On Amendments to the Law of Ukraine "On the Arbitration Court" defined the procedure for the implementation of this Law.

According to the Law of Ukraine 'On Commercial Courts', the Commercial Court of the Autonomous Republic of Crimea, commercial courts of regions, cities of Kyiv and Sevastopol were envisaged in the system of local commercial courts of Ukraine. According to the proposal of the Head of the Supreme Commercial Court of Ukraine, the President of Ukraine could form other local commercial courts (city, inter-district, of special (free) economic zones, etc.). Extremely important functions in the administration of justice in commercial relations were relied on appeal commercial courts. According to Article 91 of the Law of Ukraine 'On Commercial Courts', appellate commercial courts were declared to be courts of appellate instance. They were formed by the President of Ukraine on the proposal of the Head of the Supreme Commercial Court of Ukraine with defining the territory to which the powers of appellate commercial courts apply and their location. Article 10 of the Law of Ukraine 'On Commercial Courts' stated that 'the Supreme Commercial Court of Ukraine is the highest judicial body of commercial courts of Ukraine in the administration of justice in commercial relations.' The Supreme Commercial Court of Ukraine consisted of the Head, the First Deputy Head, deputy heads and judges, and was to act as a member of the panel of judges. The Supreme Commercial Court of Ukraine established a Presidium as an advisory body to the Head of the Supreme Commercial Court of Ukraine. Undoubtedly, the introduction of appellate commercial courts has become one of the most important innovations in the system of commercial courts of Ukraine. They were formed in July 2001 by the Decree of the President of Ukraine 'On the Establishment of Appeal Commercial Courts of Ukraine' in the number of seven courts, namely: Dnipropetrovsk, Donetsk, Kyiv, Lviv, Odesa, Sevastopol and Kharkiv Commercial Courts of Appeals, with the definition of the territory to which the powers of appellate commercial courts were distributed.

The Law of Ukraine 'On Commercial Courts' expired with the entry into force of the Law of Ukraine 'On the Judiciary of Ukraine' on 1 June, 2002, which can be considered as the completion of the first stage of judicial reform. In general, it had a positive influence, since it secured the status of specialized courts, outlining the powers of their heads, the procedure for appointing judges to administrative positions, etc, the three link system of specialized commercial courts was approved: local commercial courts (commercial courts of the Autonomous Republic of Crimea, regions, cities of Kyiv and Sevastopol), appellate commercial courts and 
the Supreme Commercial Court of Ukraine. In March 2003 in accordance with the Law of Ukraine 'On the Judiciary of Ukraine', the Supreme Commercial Court of Ukraine established court chambers for the consideration of certain categories of cases: the court chamber for the consideration of cases arising from tax and other relations concerning state regulation of activities of commercial entities; the court chamber for the consideration of cases in commercial disputes related to the protection of the right to intellectual property; the court chamber for the consideration of cases in disputes between business entities; the court chamber for the consideration of cases of bankruptcy.

The next stage of the reform of the commercial court system was marked by the adoption on 7 July, 2010 of the Law of Ukraine 'On the Judiciary and Status of Judges', which defined the organization of the administration of justice, the system of courts of general jurisdiction, the status of judges, the procedure for the implementation of judicial self-government, etc. The adoption of the abovementioned law can be considered a significant step towards the creation of an accessible and efficient judicial system in accordance with the Constitution of Ukraine and international standards in the field of justice. In order to enforce the provisions of this Law and for the proper provision of effective work in the new conditions, the specialization of judges and, on the proposal of the Head of the Court, their distribution among the four newly created chambers of courts was determined on the meeting of judges of the High Commercial Court of Ukraine.

\subsection{Modern Reform of the Courts of Commercial Jurisdiction}

The final stage of the reform of commercial courts and commercial justice as a whole was the adoption of the Law of Ukraine 'On the Judiciary and Status of Judges', the Law of Ukraine 'On Amendments to the Commercial Procedural Code of Ukraine, the Civil Procedural Code of Ukraine, the Code of Administrative Legal Proceedings of Ukraine and Other Legislative Acts' of 3 October 2017, the Decree of the President of Ukraine No. 454/2017 'On Liquidation of Appellate Commercial Courts and Establishment of Appellate Commercial Courts in Appellate Circuits', the Decree of the President of Ukraine №453/2017 'On Liquidation of Local Commercial Courts and the Formation of Circuit Commercial Courts'.

Thus, according to Part 2 of Art. 21 of the Law of Ukraine 'On the Judiciary and Status of Judges'. local commercial courts are district commercial courts ${ }^{142}$. In addition, according to Part 3 of Art. 26 of the same Law, the appellate courts for consideration of commercial cases, and the appellate courts for consideration of administrative cases are the appellate commercial courts and the appellate administrative courts respectively, created in respective appellate circuits ${ }^{143}$.

In the procedure for reviewing the decisions of local and appellate commercial courts,

142 The Decree of the President of Ukraine 453/2017 'On the Liquidation of Local Economic Courts and Establishment of Economic Courts in Circuits' < www.president.gov.ua/ documents/4532017-23370> accessed 3 November 2018

143 The Decree of the President of Ukraine 454/2017 'On Liquidation of Appelate Economic Courts and Establishment of Appelate Economic Courts in Appelate Circuits' <https://www.president. gov.ua/documents/4542017-23366> accessed 3 November 2018 
the Cassation Commercial Court was determined as a part of the Supreme Court by the cassation instance. In addition to the constant three-stage system of commercial courts, there are instances when the case during the consideration by the Court of Cassation may be referred to the Grand Chamber of the Supreme Court. Thus, according to Art. 303 of the Civil Code of Ukraine, the issue of referral of a case to the Chamber, the Joint Chamber or the Grand Chamber of the Supreme Court is decided by the court on its own initiative or at the request of the party to the case.

The issue of referral of a case to the Chamber, the Joint Chamber or the Grand Chamber of the Supreme Court shall be decided by the majority of the composition of the court hearing the case. The court shall rule on the transfer of the case to the Chamber, the Joint Chamber or the Grand Chamber of the Supreme Court, stating reasons for the need to deviate from the conclusion on the application of the law in similar legal relationships set forth in the decision specified in the first to fourth paragraphs of Article 302 of this Code, or with the justification of the grounds, specified in parts five or six of Article 302 of this Code.

According to statistics of the Supreme Court, during the first half of 2018, 10,723 cassation complaints were considered by the Commercial Court of Cassation; 168 cases were transferred to the Grand Chamber of the Supreme Court; 8,544 cases were considered overall; 1134 cases were refused to be opened in cassation proceedings; 1,628 cassation appeals were returned; 4,278 cassation appeals were refused to be satisfied and the court decision was left unchanged; 1,369 cassation appeals were satisfied and the court decisions were revoked; 2,011 cassation appeals remain to be considered by the end of the period ${ }^{144}$.

Analysing the statistics one can see a significant load on the Court of Cassation. These statistics of the court of cassation are impressive, looking at the number of judges who are considering commercial cases. Thus, in the composition of the Court of Cassation, today, justice is administered by 27 judges, which are divided between the court chamber for the consideration of bankruptcy cases, the court chamber for the consideration of cases on the protection of intellectual property rights, as well as those related to anti-monopoly and competition law, the court chamber for consideration of cases on corporate disputes, corporate rights and securities, the court chamber for consideration of cases concerning land relations and property rights, and 4 judges elected to the Grand Chamber.

\section{NOVELS OF COMMERCIAL PROCEDURE IN THE CONTEXT OF JUDICIAL REFORM}

\subsection{New Approaches in Determining the Purpose and General Principles of Commercial Legal Proceedings}

In connection with the adoption of the new wording of the Commercial Procedural Code, a norm regarding its appointment appeared for the first time. Thus, accord-

144 Statistics of the Supreme Court of Ukraine for the First Half of $2018<$ https://supreme.court.gov. ua/supreme/pokazniki-diyalnosti/sud_statistika/> accessed 3 November 2018 
ing to Art. 1 of the CPC of Ukraine, the Commercial Procedural Code of Ukraine defines the jurisdiction and powers of commercial courts, and establishes the procedure for the execution of legal proceedings in commercial courts.

The unification of procedural legislation was a result of the introduction of European standards of legal proceedings, which both directly and indirectly derive from Art. 6 of the European Convention on Human Rights and Fundamental Freedoms, which enshrined that everyone in the determination of his/her civil rights and obligations or in any criminal charge against him/her, has the right to a fair and public hearing of a case within a reasonable time by an independent and impartial court created on the basis of law. As the European Court of Human Rights has pointed out, "the Convention seeks to protect not theoretical or illusory, but specific and effective rights. This comment concerns, in particular, the right of access to justice, taking into account the prominent place that holds the right to a fair trial in a democratic society." ${ }^{145}$

Thus, in the process of harmonization of the commercial procedural legislation, the basic ideas (principles) have undergone some changes, and, in some cases, were introduced for the first time in commercial legal proceedings.

The principle of transparency of the court process and the openness of information on the case are more widely disclosed (Article 8-9 of the CPC of Ukraine). Such an approach to the implementation of the principle of transparency was mainly the practice of the EHRC. In accordance with paragraph 56 of the ECHR judgment in the case of 'Shagin v Ukraine', the court reiterates that ensuring the openness of a trial is a fundamental principle enshrined in Article 6 paragraph 1. Such a public nature of the trial guarantees the parties to the case that justice will not be enforced secretly, without public control; it is also one of the means of maintaining trust in the courts and the administration of justice, as the trial acquires legitimacy through publicity. By ensuring transparency in the administration of justice, publicity contributes to the realization of the objective of Article 6, paragraph 1, namely, to a fair trial, the maintenance of which is one of the fundamental principles of a democratic society within the meaning of the Convention.

The principle of proportionality in commercial legal proceedings was introduced for the first time. Thus, under the proportionality of the commercial procedure, it is proposed to understand the following: the court determines, in the limits established by this Code, the category of proceedings in accordance with the principle of proportionality, taking into account the problems of commercial justice, the peculiarities of the subject of the dispute, the price of the claim, the complexity of the case, the importance of the consideration of the case for the parties, the time required for commission an action, the amount of legal expenses and other expenses of the parties related to the corresponding procedural actions. Without denying the importance and expediency of consolidating such a principle of commercial justice in general, it seems necessary to note several aspects of its implementation.

145 M De Salvia, Test Cases of the European Court of Human Rights: Guiding Principles of the Jurisprudence Relating to the European Convention for the Protection of Human Rights and Fundamental Freedoms: Judicial practice from 1960 to 2002 (Jurid Center Press 2004) 284. 
It is worthwhile to support the opinion that not the court, but the will of the applicant should be the driving force of civil justice. Empowering the court to determine the category of proceedings in the case infringes the principle of discretion and the applicant's right to choose the procedure for the protection of his rights. A simplified procedure for reviewing cases should be an effective alternative to the general way of resolving them, but it is the applicant who chooses to use it, rather than the court. We are also biased in regards to proposals for the definition of specific categories of cases, for which a mandatory simplified procedure has been defined (Article 247 of the CPC of Ukraine) ${ }^{146}$. Such a mechanism was provided in national legislation by introducing the differentiation of proceedings and the presence of simplified procedure for the consideration of specific categories of cases along with the general procedure. Among the most well-known examples of the rational mechanisms for reducing the cost and length of litigation are the order proceedings, which are now in the law of almost every state. With this in view, we support the proposed differentiation of the order, simplified and general procedure of commercial proceedings.

\subsection{Introduction of E-justice}

One element of modernization, which is reflected in the civil, administrative, as well as commercial legal proceedings, is the introduction of the Single Judicial Information and Telecommunication System, the essence of which is disclosed in Art. 6 of the CPC of Ukraine. Thus, statements of claim and other applications, appeals and other statutory procedural documents which are submitted to the commercial court and may be subject to judicial review, are subject to mandatory registration in the Single Judicial Information and Telecommunication System on the day of receipt of the documents in the order of their receipt.

The appointment of a judge or panel of judges (judge-rapporteur) for the consideration of a particular case is carried out by the Single Judicial Information and Telecommunication System in the manner determined by this Code (automated division of cases).

The single judicial information and telecommunication system, in accordance with the law, provides for the exchange of documents (sending and receiving of documents) in electronic form between courts, between the court and the participants in the trial, between the participants in the judicial process, as well as the recording of the trial in video conference mode.

The court shall forward court decisions and other procedural documents to the participants of the court process at their official electronic addresses, perform other procedural actions in electronic form using the Single Judicial Information and Telecommunication System in accordance with the procedure established by this Code and the Regulation on the Single Judicial Information and Telecommunication System.

Attorneys, notaries, private executives, arbitrage managers, court experts, state bodies, local governments and commercial entities of the state and municipal sectors

146 Iryna Izarova, 'Principle of proportionality in the EU civil process and prospects for its introduction in the civil process of Ukraine' (2016) 37 (1). Scientific Bulletin of Uzhgorod National University. Series: Law 127-130 <http://nbuv.gov.ua/UJRN/nvuzhpr_2016_37\%281\%29_33> accessed 3 November 2018 
of the economy register official electronic addresses in the Unified Judicial Information and Telecommunication System in a mandatory manner. Other persons register their official electronic addresses in the Unified Judicial Information and Telecommunication System on a voluntary basis.

For persons who have registered official electronic addresses in the Single Judicial Information and Telecommunication System, the court shall hand over any documents in cases in which such persons participate, exclusively in electronic form, by sending them to the official electronic addresses of such persons, which does not deprive them of their right to receive a copy of the court decision in paper form on a separate application.

Registration in the Single Judicial Information and Telecommunication System does not deprive the right to submit documents to the court in paper form.

Persons who registered official electronic addresses in the Single Judicial Information and Telecommunication System may file procedural and other documents, perform other procedural actions in electronic form solely with the help of the Single Judicial Information and Telecommunication System, using their own electronic digital signature, equivalent to a personal signature in accordance with the Law of Ukraine 'On Electronic Digital Signature', unless otherwise is provided by this Code.

The peculiarities of the use of electronic digital signature in the Single Judicial Information and Telecommunication System are determined by the Regulation on the Single Judicial Information and Telecommunication System.

The court conducts consideration of the case on the materials of the court case in electronic form. Procedural and other documents and proofs in paper form shall be converted into electronic form not later than three days from the date of their receipt to the court and will be attached to the materials of the electronic court case in accordance with the procedure established by the Regulation on the Single Judicial Information and Telecommunication System.

If it is impossible for the court to consider the case in electronic form for technical reasons for more than five days, which may prevent the consideration of the case within the terms established by this Code, the case shall be considered on the basis of the materials in paper form, for which the materials of the case are immediately converted into a paper form in the order, established by the Regulation on the Single Judicial Information and Telecommunication System.

Procedural and other documents and evidence in paper form are stored in the annex to the case in the court of first instance and, if necessary, may be inspected by the participants in the case or by the court of first instance or requested by the court of appeal or cassation after receipt of the corresponding appeal or cassation appeal.

\subsection{Differentiation of Commercial Legal Proceedings}

Another novel of the commercial procedural legislation is the approval of the forms of commercial proceedings. Thus, according to Art. 12 of the CPC of Ukraine, commercial legal proceedings are carried out according to the rules pro- 
vided for in this Code, in particular, under: 1) order proceedings; 2) action proceedings (general or simplified).

Regarding the consideration of the case under order procedure, the legislation stipulates that the court order may be issued only on the basis of the requirements for collecting monetary debts under a contract concluded in writing (including electronic), if the amount of the claim does not exceed one hundred subsistence minimums for able-bodied persons.

A person has the right to apply to the court with the requirements specified in part one of this article under simplified procedure on his or her choice.

The general proceedings are intended for consideration of cases which due to complexity or other circumstances are inappropriate to be considered in simplified proceedings. According to Part 3 of Art. 12 of the CPC of Ukraine, simplified order proceeding is intended for consideration of small claims, cases of low complexity and other cases, for which the priority is a quick solution to the case.

The conditions, under which a court has the right to consider claims for recovery of money in the order proceedings, and consider cases in general or simplified proceedings, are determined by the CPC. The following cases are to be considered under simplified procedure:

1) small claims which value does not exceed one hundred sizes of subsistence minimums for able-bodied persons;

2) cases of low complexity, which are recognized as cases to be considered under simplified procedure by court, except cases that are to be considered only in accordance with the rules of general proceedings, and cases where the value of a claim exceeds five hundred subsistence minimums for able-bodied persons.

Differentiation of the categories of cases of general and simplified proceedings is specified in Article 244 of the CPC of Ukraine, according to which any case that is subject to the jurisdiction of commercial court, with the exception of cases specified in part four of this article, may be considered in simplified proceedings.

When deciding on the consideration of a case under simplified or general procedure, the court shall take into account:

1) the price of the claim;

2) the significance of the case for the parties;

3) the method of protection chosen by the plaintiff;

4) the category and complexity of the case;

5) the scope and nature of the evidence in the case, including whether it is necessary to appoint an expert examination, to summon witnesses, etc.;

6) the number of parties and other participants in the case;

7) whether the consideration of the case is a significant public interest;

8) the opinion of the parties on the need to consider the case under the rules of simplified proceedings.

The following cases cannot be considered in simplified proceedings:

1) on bankruptcy; 
2) on applications for approval of plans to reorganize the debtor before opening of proceedings in the bankruptcy case;

3) on disputes arising out of corporate relations, and disputes concerning transactions in respect of corporate rights (shares);

4) on disputes concerning the protection of intellectual property rights, in addition to cases of collection of a monetary amount which does not exceed one hundred subsistence minimums for able-bodied persons;

5) on disputes arising from relations concerning the protection of economic competition, restriction of monopoly in commercial activity, protection against unfair competition;

6) on disputes between a legal entity and its official (including an official whose powers have been terminated) on compensation for losses caused by such an official to a legal entity by his/her actions (inaction);

7) on disputes concerning the privatization of state or communal property;

8) in which the value of the claim exceeds five hundred subsistence minimums for able-bodied persons;

9) other requirements combined with the requirements in the disputes specified in paragraphs 3-8 of this part.

The court refuses to consider the case under simplified procedure or decides to hear a case under the rules of general proceedings, if, after the court has chosen to consider the claim of the plaintiff to increase the amount of claim or change the subject of the claim, the respective case cannot be considered under the rules of simplified summary proceedings.

\subsection{Definition of Written Statements of Participants in the Case and Written Form of Proceedings in the Case}

The clear definition of statements concerning the case is a no less important novelty of commercial proceedings. In accordance with Art. 161 of the CPC of Ukraine, when considering a case by a court under action procedure, the participants of the case shall lay down their claims, objections, arguments, explanations and arguments regarding the subject of the dispute exclusively in statements concerning cases specified by this Code in writing.

Statements concerning the case are: a statement of a claim; a statement of defence (defence) ; a reply to a statement of defence (replication); objection; explanation of a third party regarding a claim or a defence.

Each of these applications provides for appropriate requirements and the consequences of non-compliance with such requirements.

A) Statement of a claim. A statement of a claim is submitted to the court in writing and signed by the plaintiff or his/her representative or another person who has the right to apply to the court in the interests of another person.

A statement of a claim shall contain, in addition to already established items, indication of the price of the claim, if the claim is subject to monetary evaluation; 
reasonable calculation of the amounts collected or disputed; information on taking measures of pre-trial settlement of a dispute - if the law establishes a mandatory pretrial procedure for settling a dispute; information on taking measures to provide evidence or a claim before filing a statement of claim, if any; preliminary (indicative) calculation of the amount of court costs incurred by the plaintiff and expected to be incurred in connection with the consideration of the case; confirmation of the plaintiff that he or she has not filed another claim (claims) to this same defendant (defendants) with the same subject and for the same reason.

A statement of a claim shall be accompanied, in addition to the traditional ones, by documents confirming the sending of copies of the statement of claim and the documents attached thereto to other participants of the case; as well as payment of court fees in the established order and amount, or documents confirming the grounds for exemption from payment of court fees in accordance with the law.

The plaintiff is obliged to add all evidence available to him/her to the statement of claim that confirms the circumstances on which the claims are based (if a written or electronic evidence is submitted, the plaintiff can attach a copy of the relevant evidence to the claim statement).

In case of necessity, a claim application for the appointment of an examination, recourse to evidence, etc. is attached to the statement of claim.

B) Statement of defence. According to Art. 165 of the CPC of Ukraine, the defendant lays out objections to the claim in a statement of defence.

A statement of defence is signed by the defendant or his/her representative.

In case of full or partial recognition of claims, a statement of defence must contain claims that are recognized by the defendant; circumstances that are recognized by the defendant, as well as legal assessment of the circumstances provided by the plaintiff, with which the defendant agrees; objections (if any) to the circumstances and legal grounds of the claim, which the defendant does not agree with, with reference to relevant evidence and law; a denial (if any) regarding the amount of legal expenses claimed by the plaintiff, which the plaintiff has incurred and pending before the end of the consideration of the case on merits; preliminary (indicative) calculation of the amount of court costs incurred by the defendant and which is expected to incur in connection with the consideration of the case.

If the statement of defence does not contain an indication of the defendant's disagreement with any of the circumstances on which the claims are based, the defendant will be deprived of the right to object to such a circumstance during the consideration of the case on the merits, except cases where the disagreement with such a circumstance is apparent from the evidence, substantiating his/her objections in essence to the claims, or the defendant will prove that he/she has not objected to any of the circumstances on which the claims are based on grounds that are not under his control.

A copy of a statement of defence and the documents attached thereto must be filed (provided) to the other participants of the case at the same time as sending (providing) a statement of defence to the court. 
The following are added to a statement of defence:

1) Evidence confirming the circumstances on which the defendant's objections are based, if such evidence is not provided by the plaintiff;

2) documents confirming the sending (provision) of the statement of defence and the evidence attached thereto to other participants of the case.

To the statement of defence, signed by the representative of the defendant, a power of attorney or other document confirming the powers of the representative of the defendant is attached. The statement of defence is submitted within the time limit set by the court, which may not be less than fifteen days from the date of the order to open the proceedings. The court should set a deadline for the submission of a statement of defence, which will allow the defendant to prepare it and the relevant evidence, and to other participants of the case to receive a statement of defence no later than the first preparatory meeting in the case. In case of failure to provide the defendant with a revocation within time determined by the court without valid reasons, the court will settle the case on merits.

C) Reply to statement of defence. According to Art. 166 of the CPC of Ukraine, the plaintiff sets out his/her explanations, arguments and arguments regarding the respondent's statement of defence to the objections and the reasons for their recognition or rejection in a reply to a statement of defence. A reply to a statement of defence is signed by the plaintiff or his representative. . A reply to a statement of defence is submitted within the time limit set by the court. The court should set a deadline for filing a reply, which will allow the plaintiff to prepare his/her arguments and relevant evidence, and it will allow other participants of the case to receive a reply to a statement of defence in advance of the beginning of the consideration of the case on merits, and the defendant will be able to provide the participants with the objection in advance of the commencement of consideration of the case on merits.

D) Objection. In an objection the defendant sets out his/her explanations and arguments regarding the answers given by the plaintiff in a reply to a statement of defence, reasoning and argument, and the reasons for their recognition or rejection. The objection is signed by the defendant or his/her representative. The objection is filed within the time limit set by the court. The court should set a time limit for filing an objection, which would allow other participants to receive an objection in advance of the commencement of consideration of the case on merits (Article 167 of the CPC of Ukraine).

E) Explanation of a third party regarding a claim or a defence. In the explanations of a third person regarding a claim or a statement of defence, a third person who does not declare independent claims regarding the subject of the dispute, sets out his/her arguments and thoughts in support or objection to the claim. Explanations of a third person are signed by a third party or its representative. Explanations of a third person are filed within the time limit set by the court. The court should set a term that allows a third person to prepare his/her arguments and relevant evidence, and to provide an explanation to the claim or to the statement of defence, while other parties to the case will be able to respond to such explanations in advance of the commencement of the consideration of the case on merits (Article 168 of the CPC of Ukraine). 
6. As for the disclosure of the legal status of other participants in the trial, the Commercial Procedural Code allocates such a new subject of commercial legal relations as a legal expert. To be involved as a legal expert, a person shall have a degree and be recognized as a professional legal expert. The decision on the admission to participation in the case of a legal expert and the attachment of his/her conclusion to the case file is made by the court.

A legal expert is obliged to appear in court on its summons, to answer questions put by the court, to provide clarification. In the absence of objections of the participants in the case, a legal expert can participate in the court session in the video conference mode.

A legal expert has the right to know the purpose of his or her summons to court, to refuse to participate in the trial, if he/she does not have the relevant knowledge, as well as the right to payment for services and compensation of costs associated with a summons to a court.

In accordance with Art. 108 of the CPC of Ukraine, participants in the case have the right to bring to court the expert opinion in the field of law regarding:

1) application of the analogy of the law, the analogy of the judiciary;

2) the content of the rules of foreign law in accordance with their official or generally accepted interpretation, practice of application, doctrine in the relevant foreign state.

The conclusion of a legal expert cannot contain an assessment of evidence, indications of the authenticity or unreliability of a particular evidence, the merits of one evidence over others, which decision should be taken on the outcome of the case.

The expert's conclusion is not taken as evidence, has a subsidiary (advisory) character and is not binding on the court.

The court can refer in its decision to the opinion of a legal expert as the source of the information contained therein, and must make independent judgments on relevant issues.

\subsection{Improvement of the Procedure of Proof in the Case}

The current CPC of Ukraine regulates a new approach to evidence and means of evidence in accordance with the requirements of case management. In accordance with Art. 73 of the CPC of Ukraine, evidence is any data on the basis of which the court establishes the presence or absence of circumstances (facts) justifying the claims and objections of the participants in the case, and other circumstances that are relevant for the resolution of the case.

The outcome of the case depends on what the participants in the case substantiate their claims and objections with. It is in the courtroom during the decision of the court where the court gives a complete assessment of all the evidence during the consideration of the case. An example is the following practice of the Supreme Court. In refusing to comply with the cassation appeal, the Cassation Commercial Court in its ruling of 6 July 2018 in the case No. 4/428 on the appeal of the State Enterprise of Re- 
gional Electric Networks “R. E. M." represented by the Luhansk Branch of 7 July 2017 against action of the Division of Decisions Enforcement of the Department of State Bailiff Service of the Ministry of Justice of Ukraine noted that, following the decision of the European Court of Human Rights dated 18 July, 2006 in the case of "Pronin versus Ukraine", analysing the completeness of the investigation by the courts of the circumstances of the case, the Court notes that Article 6 paragraph 1 of the Convention does not bind the national courts to provide a detailed answer to every argument put forward by the applicant (parties to the case). Courts have a duty to justify their decisions, but this cannot be taken as a requirement to provide a detailed answer to every argument. The boundaries of this duty may vary, depending on the nature of the decision. The question whether the court fulfilled its obligation to submit a substantiation arising from Article 6 of the Convention may be determined only in the light of the particular circumstances of the case. By analysing, in the light of the above mentioned conclusions of the ECHR, the completeness of investigation by the courts of the circumstances of the case and the justification the court decisions, the Court agrees with the performing by the courts of first and appellate instances of their duty to substantiate their conclusions and does find a violation of the substantive and procedural law that could result in the abolition of the adopted decisions by the courts ${ }^{147}$.

Thus, in accordance with the norms of the current commercial procedural law, the data of the parties, by which they substantiate their claims and objections, are established by the following means: 1) by written, substantive and electronic evidence; 2) by expert opinions; 3 ) by testimony of witnesses.

Thus, evidence of witnesses and electronic evidence are among the means of proof that are new to commercial justice.

A witness's testimony is a statement about circumstances known to him/her that are relevant to the case. Evidence of a witness who cannot name the source of his/her knowledge, or evidence based on other people's statements is not considered to be facts of evidence.

Circumstances (facts) that, in accordance with the legislation or business practices, are to be reflected (recorded) in relevant documents cannot be established based on the testimony of witnesses. The law may specify other circumstances that cannot be established on the basis of witness testimony.

Parties, third parties and their representatives, with their consent, including on their own initiative, unless otherwise provided by this Code, may be questioned as witnesses on circumstances known to them that are relevant to the case.

The testimony of a witness based on the reports of other persons is not taken into account by the court.

The participant in the case has the right to put in the first statement concerning the case or in the annex to it not more than ten questions to another party to the case about the circumstances relevant to the case.

147 Decree of the Supreme Court in the Name of Ukraine 6 July 2018 Case 4/428 <http://reyestr.court. gov.ua/Review/75637076> accessed 3 November 2018 
The participant of the case, who is asked by the other party to the case, is obliged to provide an exhaustive answer separately for each question on the merits.

If the participant of the case is a legal entity, the answer to questions is provided by its head or other official on its behalf.

Answers to the questions shall be submitted to the court by the participant of the case: an individual, a manager or other official of the legal entity in the form of a statement of the witness not later than five days before the preparatory meeting, and in the case considered in the simplified proceedings - five days before the first court hearing.

A copy of such a statement of the witness within the same period shall be sent to the party to the case who has submitted written questions.

According to Art. 96-97 of the CPC of Ukraine, electronic evidence is data in electronic (digital) form, which contains information about circumstances relevant to the case, in particular, electronic documents (including text documents, graphic images, plans, photographs, video and audio recordings etc.), websites (pages), text, multimedia and voice messages, metadata, databases and other data in electronic form. Such data can be stored, including on handheld devices (memory cards, mobile phones, etc.), servers, backup systems, elsewhere in electronic form (including the Internet).

Electronic evidence is filed in the original or in electronic copy, certified by an electronic digital signature, equivalent to a personal signature in accordance with the Law of Ukraine "On Electronic Digital Signature". The law may provide for another procedure for certifying an electronic copy of electronic evidence.

The participants in the case have the right to file electronic evidence in paper copies certified in accordance with the procedure provided for by law. A paper copy of electronic evidence is not considered to be a written evidence. The participant of the case, who submits a copy of the electronic evidence, shall indicate that he/she or the other person has the original electronic evidence.

If a copy (paper copy) of electronic evidence is filed, the court may, at the request of the participant in the case or on its own initiative, request the original of the electronic evidence from the relevant person. If the original of the electronic evidence is not filed and the participant or the court questions the conformity with the submitted copy (paper copy) of the original, such evidence is not taken into account by the court.

Originals or copies of electronic evidence are kept by the court in the case file.

At the request of the person who provided the court with the original electronic evidence on a material carrier, the court returns such material carrier containing the original evidence to that person after examining the said electronic evidence, if possible, without prejudice to the consideration of the case, or after the entry of a judicial decision into force. In the case file, a copy of the electronic evidence or an extract from it is certified by a judge. 


\subsection{New Approaches to the Distribution of Court Costs in the Case}

Apart from the above-mentioned novel procedural institutes, the preliminary payment of court expenses and its provision are also the relevant ones. Thus, according to Art. 124-125 of the CPC of Ukraine, together with the first statement on the merits of the dispute, each party submits to the court a preliminary (indicative) calculation of the amount of legal expenses that it incurred and which is expected to incur in connection with the consideration of the case.

In the event that the party fails to make a preliminary calculation of the court costs, the court may refuse to reimburse the party for the corresponding legal expenses, except for the amount of the court fee paid by the party.

The preliminary calculation of the court costs does not restrict the party from the substantiating of another actual amount of court costs, which is subject to division between the parties on the outcome of the proceedings.

The court may pre-determine the amount of court costs (except for the cost of professional legal assistance) related to the consideration of a case or a certain procedural action. Such a court's pre-determined amount does not limit the court to the final determination of the amount of court costs that are subject to division between the parties on the outcome of the proceedings.

The court may require the parties to deposit a pre-determined amount of court costs related to the consideration of a case or a certain procedural action on a deposit account of a court, as decided by the court (provision of legal expenses).

The court may oblige the participant who filed a claim for a witness summon, appointment of an expert, the involvement of a specialist, translator, provision, reclamation of evidence or evidence examination at its location, to pay in advance the costs associated with the relevant procedural act.

If several parties have filed a motion, the necessary amount of money in advance shall be paid in equal shares by the respective participants of the case, and in cases where the relevant procedural act is carried out on the initiative of the court, the parties shall pay in equal shares.

If the court costs are not paid in the time period defined by the court, or if the court does not receive the relevant sum in advance in the defined time period, the court is entitled to reject the application for a witness, the appointment of an expert examination, the involvement of a specialist, an interpreter, provision, reclamation or review of evidence, and to make a decision on the basis of evidence submitted by other participants in the case or cancel a previously issued decision on the call of a witness, the appointment of an expert examination, the involvement of a specialist, translator, provision, reclamation of evidence or examination of evidence at its location.

As a measure to secure the court costs, the court, having regard to the particular circumstances of the case, has the right, at the request of the defendant, to oblige the plaintiff to deposit a sum of money on the deposit account of a court in order to ensure that the defendant may receive future compensation for the professional 
legal assistance and other expenses incurred by the defendant in connection with the consideration of the case (provision of expenses for professional legal assistance).

Such security for court costs apply if:

1) the claim has signs of knowingly groundless or other signs of abuse of the right to sue;

2) the plaintiff has no place of residence (stay) or location on the territory of Ukraine and property registered on the territory of Ukraine in the amount sufficient to cover the court costs of the defendant in case of refusal of the claim.

Such security for court costs can also be applied if evidence is provided to the court that the property of the plaintiff or his/her actions in relation to the alienation of property or other actions may complicate or make it impossible to enforce a court decision to reimburse the defendant's court costs in the event of a refusal of the claim.

The amount of provision for expenses for professional legal assistance is determined by the court, taking into account the requirements of part four of Article 126, part five of Article 127 and part five of Article 129 of this Code, as well as their documentary substantiation.

Thus, in the ruling of the Cassation Commercial Court of 24 October, 2018, in case No. 910/19576/17, on the claim of the private transport enterprise "D." to the public joint stock shipping company 'S.K.U.' on collection of 244,579.94 UAH, it is stated that when determining the amount of compensation, the court should proceed from the criterion of the reality of lawyer's expenses (establishing their validity and necessity), as well as the criterion of reasonableness of their size, based on the particular circumstances of the case and the financial situation of both parties. The European Human Rights Court applies the same criteria when appointing legal costs under article 41 of the Convention, in particular, according to its practice, the applicant has the right to compensation for court and other expenses only if it is proved that such expenses were actual and inevitable and their amount was justified ('East/West Alliance Limited $v$ Ukraine' judgment, application no. $19336 / 04)^{148}$.

In case of failure to deposit the funds for the provision of expenses for professional legal assistance in a set term the court, at the request of the defendant, has the right to leave the claim without consideration.

In case of satisfaction of a claim, the court decides on the return of the amount paid to the plaintiff, and in case of refusal of the claim, closure of the proceeding or abandonment of the claim without consideration the court decides on compensation of the defendant fully or in part at its expense in the manner prescribed by Articles 129, 130 of this Code. The unused amount deposited by the plaintiff is returned to the plaintiff not later than five days from the day the issues referred to in this part are resolved, for which the court makes the decision.

148 Decree of the Supreme Court in the Name of Ukraine of 24 October 2018 Case 910/19576/17 < http://reyestr.court.gov.ua/Review/77431906> accessed 3 November 2018 


\subsection{Prevention of Abuse of Procedural Rights in the Process}

An important novelty of the new version of the CPC of Ukraine for commercial legal proceedings is the inadmissibility of abuse of procedural rights and liability for such abuse. According to Art. 43 of the CPC of Ukraine, participants in the trial and their representatives shall use procedural rights in good faith; abuse of procedural rights is not allowed.

Depending on the specific circumstances, the court may recognize the abuse of procedural rights of action that contradicts the task of commercial legal proceedings, in particular:

1) submission of an appeal to a court decision that is not subject to appeal, is not valid or expired, submission of a petition (application) to resolve a matter already decided by the court in the absence of other grounds or new circumstances, a statement of a knowingly unjustified withdrawal or the commission of other similar actions aimed at unjustifiably delaying or obstructing the consideration of a case or execution of a court decision;

2) filing several claims to one and the same defendant (defendants) on the same subject and on the same grounds or filing several lawsuits with a similar subject and for similar reasons or commiting other acts which purpose is to manipulate the automated division of cases between judges;

3) submission of a knowingly unreasonable claim, a claim in the absence of the subject matter of the dispute or in a dispute that is obviously artificial;

4) unreasonable or artificial association of claims in order to change the jurisdiction of the case, or knowingly unreasonable involvement of the person as a defendant (co-respondent) for the same purpose;

5) the conclusion of a peace agreement aimed at harming the rights of third parties, the deliberate failure to report the persons to be involved in the case.

If filing of an appeal, a statement, a petition is considered an abuse of procedural rights, the court, having regard to the circumstances of the case, has the right to leave without consideration or to return an appeal, a statement, a petition.

The court is required to take measures to prevent the abuse of procedural rights. In the event of abuse of procedural rights by a participant in a court proceeding, a court shall apply the measures specified in this Code to him/ her.

As the Cassation Commercial Court correctly states in its Resolution of 17 October.2018 in the case No. 911/1595/18 on the results of consideration of the cassation appeal of LLC 'Inter-GTV' to the decisions of the courts of first and appellate instances regarding the provision of a claim for filing a statement of claim, in paragraph 40 of Judgment of the European Court of Human Rights in case 'Hornsby v Greece' of 19 March 1997 it is stated that the execution of a judgment made by any court should be regarded as an integral part of the 'trial proceedings.' In addition, the Court has already accepted this principle in matters relating to the duration of proceedings (see cases 'Di Pede $v$ Italy' and 'Zappia $v$ Italy', judgment of 26 September 1996, Reports of Judgments and Decisions 1996-IV, pp 1383-1384, paragraphs 20-24 and pp 1410-1411, paragraphs 16-20, respectively). 
In paragraph 37 of 'Derkach and Palek $v$ Ukraine' judgment of 21 December 2004, final since 06 June 2005, the European Court of Human Rights reiterated that article 6, paragraph 1, guarantees everyone the right to file in a court or tribunal any lawsuit relating to his/her civil rights and obligations. Thus, the paragraph provides for 'the right to a court', one of the aspects of which is the right of access to a court, that is, the right to institute proceedings in a court in order to resolve a civil dispute. However, this right would be illusory if the national legal system of the High Contracting Party allowed the final, compulsory execution of the judgment to remain unenforced to the detriment of one of the parties. It is hard to imagine that paragraph 1, article 6 would describe in detail the procedural guarantees given to the parties: fairness, openness and speed of proceedings, and would not provide for guarantees of enforcement of judgments. Interpretation of Article 6 as a provision that only guarantees the right to apply to the court and to conduct a trial could lead to a situation incompatible with the rule of law that the High Contracting Parties undertook to respect when ratifying the Convention. Consequently, execution of a judgment shall be regarded as an integral part of the "trial" for the purposes of Article 6 (see 'Burdov v Russia', application No. 589498/00, paragraph 34).

For abuse of procedural rights or other actions that cause violation of the terms of consideration of the case, the court may apply measures of procedural coercion. Thus, according to Art. 135 of the CPC of Ukraine, a court may rule on the collection of a revenue to the state budget from the person concerned as a fine in the amount of one to ten times the subsistence minimums for able-bodied persons in cases of:

1) failure to perform procedural duties, in particular, evasion from the commission of actions imposed by a court on a participant in a judicial process;

2) abuse of procedural rights, commission of acts or inactivity in order to interfere with legal proceedings;

3) failure to inform the court of the impossibility of submitting evidence demanded by the court, or failure to submit such evidence without good reason;

4) failure to comply with the decision on the securing of the claim or evidence, failure to provide a copy of the request for revocation, appeal or cassation appeal, the response to the reference, the objection to another party of the case within the time limit prescribed by the court;

5) violation of prohibitions established by part ten of Article 188 of this Code.

In the case of repeated or systematic non-compliance with procedural obligations, repeated or systematic abuse of procedural rights, repeated or systematic failure to submit evidence requested by the court without good reason or without notice, the continuous non-execution of the decision to secure a claim or evidence, the court, taking into account the particular circumstances, seizes a fine in the amount of from five to fifty subsistence minimums for able-bodied people into the state budget from the relevant participant in the court proceeding or another person concerned.

In case of non-compliance with procedural obligations, abuse of procedural rights by a representative of a party to a case, the court may, with due account of the particular circumstances of the case, recover a fine from both the party's case and his/her representative. 
The decision on the recovery of a fine may be appealed in the court of higher instance. An appeal against such a decision does not preclude the consideration of the case. The decision of the court of appellate instance on the results of the review of the decision on the imposition of a fine is final and not subject to appeal.

The Supreme Court's decision on the prosecution of a fine is not subject to appeal.

The decision to impose a fine is an executive document and shall comply with the requirements of the executive document, established by law. The collector for such an executive document is the State Judicial Administration of Ukraine.

The court may revoke its resolution on the imposition of a fine if the person in respect of which it has been resolved has corrected the perceived violation and (or) provided proof of the reasons for not fulfilling the relevant requirements of the court or of his/her procedural duties.

\subsection{The Settlement of a Dispute with the Participation of a Judge}

The development of alternative dispute resolution (ADR) methods in Ukraine, as in any other country, is a complex and lengthy process. The possibility of reconciling the parties to the dispute in the courts through the achievement of a mutually acceptable solution with the assistance of a judge has always been known both to the domestic and foreign civil processes, while the way of settlement of disputes is not the main task of civil proceedings. Thus, part 1 of article. 2 of the CPC of Ukraine specifies that the task of commercial legal proceedings is a fair, impartial and timely resolution by the court of disputes related to commercial activity and the consideration of other cases assigned to the jurisdiction of a commercial court with the purpose of effective protection of violated, unrecognized or challenged rights and legitimate interests of individuals and legal entities and the state. It becomes clear that the main purpose of commercial justice is to protect the rights and interests of individuals and legal entities, as well as the state. It should be emphasized that the main purpose of mediation as an alternative way of resolving a dispute is to assist in resolving the conflict, taking into account the interests of all its parties.

Back in the 80's of the twentieth century, Italian processualist Mauro Cappelletti developed and scientifically substantiated the so-called 'three-wave' concept of development of access to justice. Under this concept, any state undergoes three stages of reform or 'waves' in order to develop access to justice. All three stages ('waves') are interdependent and aim at achieving one goal, which is the ability of various groups and categories of the population as well as individual citizens and organizations to safely restore justice. Particular attention in this study deserves a third stage ('wave') of reforms, which is associated with the introduction of various conciliatory procedures for settling disputes. A prerequisite for this is the need to eliminate the lack of conformity of the court process with the requirements of the accessibility of justice ${ }^{149}$.

149 Mauro Cappelletti, Access to Justice and the Welfare State (Publications of the European University Institute1981) 4-11. 
Previous studies identified mediation as a structured, voluntary and confidential procedure for out-of-court settlement of a dispute (conflict) in which the mediator assists the parties in understanding their interests and finding effective ways to reach a mutually acceptable solution ${ }^{150}$. The analysis of this definition and the norms of the Draft Law of Ukraine 'On Mediation' of 17 December 2015 No. 3665 gives grounds to assert that mediation is possible during the trial.

Let's pay attention to the latest civil procedural legislation related to the settlement of a dispute with the participation of a judge, provided for by Chapter 4 of the CPC of Ukraine. All articles of this chapter of the CPC of Ukraine require answers to numerous questions, such as the theory of commercial procedural law, and the practice of its application. By the time the amendments to the CPC of Ukraine were introduced within the framework of commercial procedural relations the formal possibility of a peaceful settlement of a dispute within the framework of legal proceedings was foreseen; and it is now becoming an actual reality that requires the development of a mechanism for its implementation in practice.

Settlement of a dispute with the participation of a judge is carried out with the consent of the parties before the beginning of the consideration of the case on the merits.

However, in accordance with the rules of the current commercial procedural legislation, the settlement of a dispute with the participation of a judge is not allowed in disputes (cases):

1) on the restoration of solvency of the debtor or recognition of it as a bankrupt;

2) on applications for approval of plans to reorganize the debtor before the opening of proceedings in the bankruptcy case;

3 ) in the case of a third party stating an independent claim regarding the subject matter of the dispute.

The court shall issue a ruling on conducting a dispute resolution procedure with the participation of a judge which simultaneously suspends the proceedings.

In the event when the parties fail to reach a peaceful settlement of the dispute, it is not allowed to re-conduct the dispute settlement with the participation of a judge.

The settlement of a dispute with the participation of a judge is conducted by a judgereporteur alone, regardless of the composition of the case.

The settlement of a dispute with the participation of a judge is carried out in the form of joint and (or) closed meetings. The parties shall have the right to participate in such meetings in a videoconference mode in accordance with the procedure established by this Code.

Joint meetings are held with the participation of all parties, their representatives and the judge.

150 O S Mozhaykina, 'Concepts and Contents of the Basic Principles of Mediation in Civil-Law Relations' (2017) 5 Actual questions of domestic jurisprudence. 55-58. 
Closed meetings are held on the initiative of a judge with each of the parties separately.

The judge directs the settlement of a dispute with the participation of a judge to make the parties reach the resolution of the dispute. Taking into account the specific circumstances of the meeting, the judge may announce a break within the deadline for the settlement.

At the beginning of the first joint dispute settlement meeting, the judge shall explain to the parties the purpose, the procedure for settling the dispute with the participation of the judge, the rights and obligations of the parties.

In the course of joint meetings, the judge finds out the grounds and subject of the claim, the grounds for objection, clarifies to the parties the subject of evidence regarding the category of the dispute being considered, invites the parties to submit proposals on ways of peaceful settlement of the dispute and carries out other actions aimed at peaceful settlement of the dispute by the parties. The judge may offer the parties a possible way of peaceful settlement of the dispute.

During closed meetings, the judge has the right to draw the parties' attention to court practice in similar disputes, to offer the party possible ways of peaceful settlement of the dispute.

During the settlement of a dispute, the judge has no right to provide legal advice and recommendations to the parties, to provide an assessment of the evidence in the case.

The information received by any of the parties, as well as the judge during the settlement of the dispute, is confidential. During the settlement of a dispute with the participation of a judge, the protocol of the meeting is not held and not fixed by technical means.

If required, an interpreter is involved in the meetings. The interpreter is warned about the confidential nature of the information obtained during the settlement of the dispute with the participation of a judge.

When settling a dispute with the participation of a judge, it is prohibited to use portable audio equipment, as well as to perform photo, video and audio recording.

Settlement of a dispute involving a judge is terminated:

1) in the case of submission by the party of an application for the termination of the settlement of a dispute with the participation of a judge;

2) in the case of expiration of the term of the dispute settlement with the participation of a judge;

3) upon the initiative of a judge in the case of delaying the settlement of a dispute by any of the parties;

4) in the case of the conclusion of the agreement by the parties and appeal to the court with a statement on its approval or petition of the plaintiff in court with a statement on leaving the claim without consideration, or in the event of the applicant's refusal from the claim or recognition of the claim by the defendant. 
A decision is passed on terminating a dispute with the participation of a judge, which is not subject to appeal. At the same time, the judge decides on resuming the proceedings.

The judge shall give a ruling on termination of dispute settlement with participation of a judge on the grounds provided for in paragraph 1 of this Article not later than the next working day after the receipt of the relevant application of the party, and on the grounds, established by paragraph 2 of the same part not later than the next day from the day of termination of a dispute settlement with the participation of a judge.

In case of termination of the settlement of a dispute with the participation of a judge on the grounds provided for in paragraphs 1-3 of part one of this Article, the case shall be submitted for consideration to another judge, determined in accordance with the procedure established by Article 32 of this Code.

\section{CONCLUDING REMARKS}

Today Ukraine makes significant efforts building a really constitutional democratic state on the way to the EU. The Association Agreement signed in 2014 demonstrates the desire of Ukrainian society for movement towards the European Community, particularly, ensuring access to justice and right protection according to the European Convention 's requirements. The reforms of 2015-2017 and the new legislation in the field of judicial system, legal proceedings and enforcement of judgments, adopted in Ukraine, were inspired by the high European standards.

Despite this, traditional approaches and institutions, which have been substantially updated, have to combine with the new effective mechanisms, which have been introduced into national legislation. In particular, we should preserve the effective court system, which includes general courts and commercial courts and has been established in Ukraine since its independence. Additionally, we have to contribute to a more efficient implementation of the judicial power. General and simplified procedures have been introduced in the sphere of commercial procedure, which aims and to simplify access and speed up the resolution of cases where claims are small. Idea of proportionality and case management, which is a novel in Ukrainian legislation, will provide real protection of the rights of persons. We also welcome the introduction of electronic justice, which will definitely help to solve problems of long terms and high fees of litigation, two of the weakest points in our procedure. As well as the settlement of a dispute with the participation of a judge we should create more effective and peaceful ways to ensure the rights protection.

We should admit that it is possible to estimate the achievements of reforms only from a viewpoint of their implementation, however, they need to be analysed in terms of their complexity and validity as well as in the view of attention from the side of the Ukrainian and the European society. 